\title{
Full-time versus Distance Learning of Statistics
}

\author{
Danka Lukáčová \\ Constantine the Philosopher University in Nitra, Faculty of Education, Department of Techniques \\ and Information Technologies, Dražovská 4, Post code: 949 74, Nitra, Slovakia
}

\begin{abstract}
The 2020/21 academic year was marked by the COVID-19 pandemic. Universities gradually cancelled full-time teaching and continued in the distance form. The article deals with the comparison of full-time teaching of the subject of Statistics at the University of Constantine the Philosopher in Nitra (Slovakia) and distance education. The results of the research prove that well-managed distance education can, in the case of teaching the subject of Statistics, fully replace the full-time teaching of the subject. At the same time, no significant differences were found in the results of the final didactic test between groups of full-time and part-time students taught distantly.
\end{abstract}

Keywords - COVID-19 pandemic, distance education, full-time education, Statistics, students.

\section{Introduction}

In the period of the COVID-19 pandemic, the role of independent work of university students increases significantly worldwide, with its possibilities to revitalize educational activities, form general and professional competencies, and self-education of students with the application of information and communication technologies. E-learning courses and various videoconferencing systems that schools use in teaching are important.

DOI: 10.18421/TEM111-55

https://doi.org/10.18421/TEM111-55

Corresponding author: Danka Lukáčová,

Constantine the Philosopher University in Nitra, Faculty of Education, Nitra, Slovakia.

Email: dlukacova@ukf.sk

Received: 03 November 2021.

Revised: 08 February 2022.

Accepted: 14 February 2022.

Published: 28 February 2022.

(cc)BY-NC-ND(C) 2022 Danka Lukáčová; published by UIKTEN. This work is licensed under the Creative Commons Attribution-NonCommercial-NoDerivs 4.0 License.

The article is published with Open Access at https://www.temjournal.com/
Several studies have already examined the effectiveness of online teaching. For example, V. Y. Shurigyn and L. A. Krasnova have examined the ability of Physics students to work with an e-learning course. The results of the research proved the importance and effectiveness of developed electronic educational courses in the study of Physics in the context of increasing the effectiveness of students' independent work, when a competent approach is used to increase students' competitiveness [1]. Research by other authors has shown that students are generally well prepared to use ICT during their own work and in didactic collaboration with teachers. Most students meet the requirements placed on them in basic areas such as the use of hardware and software [2]. In most cases, in classical full-time teaching, however, e-learning is used as a supplement to traditional full-time teaching, when after traditional teaching it is possible to use an elearning course to supplement, or expand the students' knowledge and skills [3].

We speak about full-time education when all students are in real time in the classroom, assuming that they all perceive at the same pace, everyone is satisfied with the way the lecturer interprets and everyone has a positive relationship to the topic at the moment [4]. Distance education is defined as the transmission of knowledge to students who are separated from the teacher in time and (or) place [5]. Keegan (1988) proposed the basic criteria that characterize distance learning: separation of teacher (tutor) from student, influence of educational organization, use of media to unite teacher (tutor) and student, ensuring two-way communication between teacher (tutor) or educational organization and student [6].

There are two basic forms of distance education distribution:

- synchronous, where all participants can communicate at the same time, the interaction between the teacher and the students takes place in real time.

- asynchronous, when students do not have to be in the same place at the same time, respectively virtual site; they do not study at the same time, the interaction does not take place at the same time [7]. 
In our case, both forms of distribution were used in distance education. In the case of synchronous distance teaching, it was the use of the videoconferencing system Meet which teachers used to communicate with students; and students used it to communicate with individual departments of the university. In the case of asynchronous distance learning, it was the use of e-learning courses in the Moodle environment, which students used at a time that suited them.

In a pandemic situation where students did not have access to the university, the focus of educational activities was on e-learning. This situation was new for both students and teachers in the spring of 2020 and it required new approaches, skills and knowledge from both groups. At the Department of Technology and Information Technologies at UKF in Nitra (Slovakia), teachers and students used two systems as a part for distance learning. One was the Meet video conferencing system, which was used mainly for live online lectures, and the other was the EDU e-learning portal, which contains courses in the Moodle environment. The content of the courses is diverse there can be published lectures in the form of presentations or videos, instructions for exercises and measurements, solved and unsolved tasks, links to videos, folders for submitting assignments and papers. Some courses were created before the COVID-19 pandemic and were used by students before the pandemic, but only as a supplement to the full-time form of teaching. At the time of the outbreak of the pandemic in 2020, for example, the course for the subject of the Statistical Methods contained only assignments for exercises - source files for solving tasks.

On March 10th in 2020, due to the outbreak of the COVID-19 pandemic, all universities in the Slovak Republic were closed and schools switched to distance education. Teachers and students stayed at home within several hours and had to adapt to distance learning. At the UKF in Nitra, the massive use of e-learning courses began in the first moment. This was mainly due to the fact that not all students and teachers in the home environment were technically equipped to use video conferencing systems (microphones, cameras, high-speed internet). Teaching took place electronically, but not in real time. Emails and discussion forums of e-learning courses were used for communication between students and teachers. So it was mostly asynchronous distance education.

In 2021, the situation was different, the technical equipment of teachers and students improved, and in addition to electronic courses, the Meet video conferencing system was used extensively for online teaching, in which all subjects were taught properly according to the schedule. Through a videoconferencing system, students had lectures, but also seminars in almost all subjects.

Over the past three academic years, three different teaching concepts have alternated at the university:

- Classical full-time teaching,

- Asynchronous distance form; using only elearning courses and e-mails,

- Both synchronous and asynchronous distance form; using e-learning courses and video conferencing system.

\section{Research Design}

The teaching of the subject of Statistical methods within the full-time teaching consists of one hour of lecture and two hours of seminars per week. Thus, students complete 13 hours of lectures and 26 hours of seminars per semester. The course ends with a test, based on which the student is evaluated. The content of the course and thus the written test are topics: history of statistics, basic statistical concepts, stages of statistical research, data preparation and statistical processing, data sorting, graphical data display, descriptive statistics of the file, and measurement of statistical dependence. During the lectures, students will get acquainted with the theoretical basis of the curriculum, then solve specific tasks in seminars. To process the source data, which they draw from the EDU e-learning portal, they use MS Excel installed on computers in a technical classroom. Students also solved the final paper at school, in a technical classroom and sent the solved tasks to the teacher by e-mail.

During distance learning with the use of e-learning courses, we added lectures to each topic in the form of presentations and sample solved tasks with a description of the solution procedure to the EDU portal, which is a part of the university intranet. At the same time, we also completed the procedure for activating the Excel - Data Analysis add-on for students. The final written test was published at a precise time through a course in the EDU portal, to which students also submitted solved tasks within a given time limit.

The distance form of education using e-learning courses and a videoconferencing system worked similarly to the full-time form of teaching according to the timetable. Lectures were held in the videoconferencing system, in the e-learning course there were lectures (presentations) on the repetition of the curriculum, source tasks for exercises, sample solutions of tasks that students could use in the repetition of the curriculum. Full-time students completed 13 hours of lectures and 26 hours of seminars through the meet videoconferencing system, external students had 10 hours of lectures 
and 10 hours of seminars. The final paper was written during the videoconference connection, while the students obtained the assignment from the elearning course, where they then inserted it in a set time.

The aim of our research was to compare the effectiveness of teaching the subject of Statistical methods over three years, which differed in teaching concepts. We assumed that distance learning could reduce the effectiveness of teaching the subject of statistical methods, which would be reflected in the learning outcomes of students. At the same time, we wanted to find out whether the application of distance education in 2021 caused statistically significant differences between the results of knowledge tests of full-time and external students. For the needs of the research, we found out the results of the final test of students who completed the subject of Statistical Methods in the years 2019-2021 at UKF in Nitra. The research was attended by 105 students from two study programs: Teaching Technology and Occupational Health and Safety. Students were taught as follows:

- Classical full-time teaching (17 students);

- Distance form; using only e-learning courses and e-mails (47 students);

- Distance form; using e-learning courses and video conferencing system (41 students).

The final test included four tasks. The first task was focused on the classification of elements of the statistical file. Students had to sort the elements and create a frequency table. The second task was focused on the graphical presentation of statistical data. The task of the students was to create a correct graph presenting the entered statistical data, which will contain the basic elements: name, axis designation, legend, numerical data. In the third task, students had to calculate the basic descriptive characteristics of the set: mean, median, mode, variance, standard deviation, skewness, sharpness. They could use Excel functions or a data analysis add-on for the calculation. The last task was focused on finding the statistical dependence (independence) of the characters. For each task, students could get 5 points, a total of 20 points from the entire test. In order for a student to succeed, it was necessary to obtain at least 12 points $(60 \%)$.

\section{Research Results}

In the research, we tested the null hypothesis: groups of students, taught by different teaching concepts, achieved the same results in the knowledge test. We verified the hypothesis by analysis of variance. The factor influencing the results of knowledge tests was a variable - a teaching concept containing three levels [8]. We performed the analysis of variance in the MS Excel environment using the ANOVA tool at the significance level $\alpha=$ 0.05 . The results of the analysis of the impact of teaching concepts on the variability of knowledge test results are shown in Table 1.

The average number of points from the written test was 16.47 points in 2019 , in 2020 it was 18.09 points and in 202117.56 points.

Table 1. Anova: Single Factor

\begin{tabular}{l|c|c|c|c|c|c}
$\begin{array}{l}\text { Source of } \\
\text { Variation }\end{array}$ & $S S$ & $d f$ & $M S$ & $F$ & $P$-value & F crit \\
\hline $\begin{array}{l}\text { Between } \\
\text { Groups }\end{array}$ & 32.77 & 2 & 16.38 & 2.61 & 0.08 & 3.09 \\
\hline $\begin{array}{l}\text { Within } \\
\text { Groups }\end{array}$ & 639.99 & 102 & 6.27 & & & \\
\hline Total & 672.76 & 104 & & & &
\end{tabular}

These values are balanced, there are no major deviations between them. The largest variance of values was observed in $2019\left(\mathrm{~s}^{2}=12.51\right)$, in subsequent years the variances were lower: 2.12 and 8.55 . The total number of points from the written test was therefore more even in 2020 and 2021 (Table 2).

\section{Table 2. Summary}

\begin{tabular}{c|c|c|c|c} 
Groups & Count & Sum & Average & Variance \\
\hline 2021 & 41 & 720 & 17.56 & 8.55 \\
\hline 2020 & 47 & 850 & 18.09 & 2.12 \\
\hline 2019 & 17 & 280 & 16.47 & 12.51
\end{tabular}

Since the calculated value of $p=0.08$ is not less than the significance level $\alpha=0.05$, we cannot reject the null hypothesis. This means that we do not reject the claim that groups of students, taught by different teaching concepts, achieved the same results in the didactic test.

Since external students had only less than half of the seminars realized by the videoconferencing system and other seminars took place in the form of self-study in the e-learning course in the educational portal EDU (asynchronous), we wanted to find out if they would not have worse results from the didactic test than full-time students.

We verified the null hypothesis: There is no difference in the results of the didactic test of fulltime and external students. We verified the hypothesis by t-test at the significance level $\alpha=0.05$. Before the t-test, we performed an F-test - a test on the equality of variances of both sets. Since the calculated value of $\mathrm{p}=0.28$, we cannot reject the null hypothesis. Therefore, in the next step, we chose a t-test for files with the same variance. The results of the t-test are presented in Table 3.

The calculated value of $p=0.84$ is greater than the set level of significance $\alpha=0.05$, therefore we do not 
reject the null hypothesis. The results of full-time and part-time students from the didactic test are not statistically significantly different.

Table 3. t-Test: Two-Sample Assuming Equal Variances

\begin{tabular}{l|c|c} 
& $\begin{array}{c}\text { full-time } \\
\text { students }\end{array}$ & $\begin{array}{c}\text { external } \\
\text { students }\end{array}$ \\
\hline Mean & 17.63 & 17.43 \\
Variance & 8.01 & 10.26 \\
Observations & 27 & 14 \\
Pooled Variance & 8.76 & \\
Hypothesized Mean & 0 & \\
Difference & 39 & \\
df & 0.21 & \\
t Stat & 0.42 & \\
P $(T<=$ t) one-tail & 1.68 & \\
t Critical one-tail & 0.84 & \\
P $(T<=$ t) two-tail & 2.02 & \\
t Critical two-tail &
\end{tabular}

\section{Conclusion}

Previous conclusions from the verification of hypotheses lead us to the conclusion that the distance education of the subject of the Statistical Methods in 2020 and 2021 was successful, as evidenced by the results of students in the final test. All compared groups of students achieved statistically comparable results in the didactic test. Students who were taught full-time, students who used asynchronous distance learning, and students who used a combination of synchronous and asynchronous distance learning achieved statistically comparable results in the didactic test. External students also achieved the same results in the didactic test as full-time students. The average values of the number of points from the didactic test 17.63 and 17.43 also correspond to this (Figure 1).

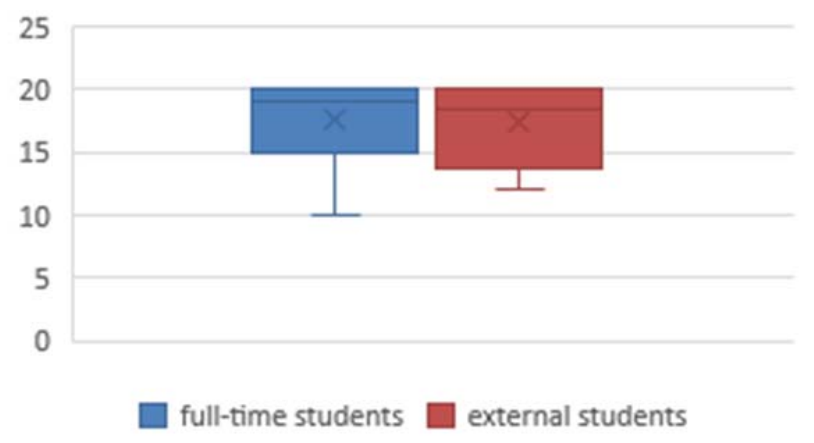

Figure 1. Comparison of points from didactic test achieved by full-time and external students

All students achieved the required number of points to obtain credits, except for two students in 2019, who obtained only 10 points in the didactic test. The content of the course, as it is currently prepared for students, meets their needs and allows students effective self-study as well as the use during video conferencing. For full-time and part-time students, the accuracy and complexity of e-learning courses is a key element in their use for teaching purposes [9]. For this reason, it is important for teachers to be able to create quality content for e-learning courses and to effectively manage distance learning. There is a need to prepare future teachers to use digital technologies and tools in the educational process, which is the role of universities [10].

The results of the didactic test for external students speak in favor of distance education. They also correspond to the results of research by other authors, e.g. Fojtik compared the average results of internal and distance students in Computer Science and stated that external students were more successful and they had deeper and better knowledge [11]. It suits these students that they can register for the course according to their needs and time possibilities and proceed independently, at their own pace, in solving the tasks. It is also easier for them to work in one electronic system than to have an open video conferencing system, an e-learning system and even MS Excel, in which they solve tasks. They like asynchronous distance education, or asynchronous education combined with synchronous distance education. The above results lead us to suggest for students of external study even outside the pandemic the possibility of combined study, i.e. the possibility to complete part of the teaching in full-time form and part partly remotely, which is more comfortable for this group of students.

\section{Acknowledgements}

Supported by the projects KEGA 014UKF-4/2020 and KEGA 012UKF-4/2020 Ministry of Education, Slovak Republic.

\section{References}

[1]. Shurygin, V. Y., \& Krasnova, L. A. (2016). Electronic Learning Courses as a Means to Activate Students' Independent Work in Studying Physics. International Journal of Environmental and Science Education, 11(8), 1743-1751.

[2]. Baron-Polańczyk, E. (2021). Using ICT Methods and Tools in the Opinions of Children and Adolescents, ICT in Educational Design Processes, Materials, Resources - KEGA Edition, 14, 11-24.

[3]. Chang, C. C., Shu, K. M., Liang, C., Tseng, J. S., \& Hsu, Y. S. (2014). Is blended e-learning as measured by an achievement test and self-assessment better than traditional classroom learning for vocational high school students?. International Review of Research in Open and Distributed Learning, 15(2), 213-231.

[4]. Frk, B. (2010). E-learning a online vzdelávanie dospelých. Pedagogika. sk, (2), 107-122. 
[5]. Hodgson, V. E., Mann, S. J., \& Snell, R. S. (1987). Beyond distance teaching towards open learning. Milton Keynes, Society for Research into Higher Education/The Open University Press.

[6]. Keegan, D. (1988). Concepts: Problems in defining the field of distance education. American journal of distance education, 2(2), 4-11.

[7]. Gajdoš, J. (2020). Distance Education. Manažment $v$ teórii a praxi, 16(4), 31-34

[8]. Chajdiak, J. (2003). Štatistika jednoducho. Bratislava: Statis.
[9]. Cheung, S. K. (2018, July). Perceived usefulness of open educational resources between full-time and distance-learning students. In International Conference on Blended Learning (pp. 357-367). Springer, Cham.

[10]. Budnyk, O., Zozuliak-Sluchyk, R., Nedilskyi, S., Chervinska, I., Malaniuk, T., Prevysokova, N., \& Ketsyk-Zinchenko, U. (2021). Modern digital distance learning technologies: challenges of future teacher training. Revista Inclusiones, 41-53.

[11]. Fojtik, R. (2015). Comparison of full-time and distance learning. Procedia-Social and Behavioral Sciences, 182, 402-407. 